\title{
Sand shinnery oak as forage for Angora and Spanish goats
}

FRANCIS VILLENA AND JAMES A. PFISTER

\section{Abstract}

Little information is available on goat nutrition and diet selection on shrub-dominated ranges. This study examined the botanical and nutritive composition of Angora and Spanish goat diets, and forage intake when grazing on sand shinnery oak (Quercus havardii Rydb.) range in west Texas during June, July, and August, 1986. A digestion trial evaluated the nutritive value of shinnery oak diets for goats. Angora and Spanish goats consumed similar amounts of shinnery oak, grass, and forbs. Their diets had similar levels of crude protein (CP), fiber, and in vitro digestibility. Consumption of oak by goats increased from $31 \%$ of diets in June to $55 \%$ in August. Dietary CP levels averaged 8.1 to $9.4 \%$ during the summer. In vitro digestibility of diets varied from 44 to $53 \%$ during the summer, with lower values during July and August. Spanish goats had higher forage intakes during July and August compared to Angora goats. Digestible energy (DE) intake (Mcal/day) did not differ between breeds, but increased during the summer. The digestion trial was conducted using 0,25 , and $50 \%$ shinnery oak with alfalfa hay. Apparent organic matter digestibility (OMD) declined linearly with increasing levels of oak; the same decline was noted for apparent $C P$ and neutral detergent, but not acid detergent, fiber digestibility. Extrapolated $\mathrm{OM}$ and CP digestibilities for $100 \%$ oak were $38 \%$ and $17 \%$, respectively. Voluntary OM intake did not differ among diets. CP and DE intakes declined linearly as dietary oak levels increased. Fecal $\mathbf{N}$ increased and urinary $\mathbf{N}$ decreased linearly with increasing levels of oak in diets. We found no evidence of intoxication from shinnery oak in grazing or pen-fed goats. Shinnery oak can contribute substantially to the nutrition of goats foraging on these ranges, but some supplemental feeding may be necessary.

Key Words: Quercus havardii, Capra hircus, browse, tannins, diet quality, goat diets

Information on the amount and nutritive quality of forage ingested by grazing animals is important to identify the constraints to efficient rangeland production of livestock. Suboptimal animal production on rangeland is the result of several factors (Hodgson

\footnotetext{
Villena was research assistant, Department of Range and Wildlife Management, Texas Tech University; presently professor, Faculty of Animal Science, Pedro Ruiz Gallo National University, Lambayeque, Peru. Pfister is range scientist, USDA-ARS Poisonous Plant Research Laboratory, Logan, Utah 84321.

The authors gratefully acknowledge research funding from USAID. C. Aguilar provided excellent technical assistance during the study, and we are indebted to her. We also thank R. Beasley for allowing use of the study site, and F. Bryant, R. Pettit, B. Dahl, M. Maiga, F. San Martin, and G. Reeves for assistance. This article is contribution No. T-9-510 of the College of Agricultural Sciences, Texas Tech University. Direct reprint requests to Pfister.

Manuscript accepted 24 May 1989.
}

1982, Allison 1985), of which nutrient intake is probably the most common (Allison 1985). Voluntary forage intake by grazing ruminants depends upon numerous intrinsic and extrinsic properties of both plants and animals (Cordova et al. 1978, Allison 1985). Recently, attention has focused on plant secondary metabolites as deterrents to herbivory (Cooper and Owen-Smith 1985) and as inhibitors of the ruminant's digestive processes (McLeod 1974). Secondary compounds in shrubs may influence both palatability and forage intake under browsing situations (Provenza and Malechek 1984).

There is a paucity of information on nutrition of goats on shrub-dominated ranges (Malechek and Provenza 1983). Further, there is little information on the comparative browsing ability or dietary selection of different breeds of goats, although there are indications that Spanish goats consume more browse than do Angora goats (Warren et al. 1984). Bryant et al. (1980) compared the nutritive value of diets selected by Angora and Spanish goats on excellent condition range on the Edwards Plateau of Texas. They suggested that although dietary protein values were acceptable for maintenance, energy levels may be inadequate when diets were composed largely of Plateau oak [Quercus virginiana var fusiformis (Small) Sarg.]. Although researchers have quantified dietary nutrient requirements for goats (Huston 1978, NRC 1981), no work has been done to characterize dietary nutrient levels of goats foraging shinnery oak (Quercus havardii $\mathrm{Rydb}$.) rangeland of which there are about 2.3 million ha in the Southwest (Sears et al. 1986). The objectives of the study were to determine the dietary nutritive quality, forage intake and diet selection of Angora and Spanish goats on shinnery oak ranges, and to quantify the nutritive value of shinnery oak for goats.

\section{Materials and Methods}

\section{Study Area}

Research was conducted from June to August 1986 in a 4-ha pasture located $\left(33^{\circ} 23^{\prime} 52^{\prime \prime} \mathrm{N}\right.$ and $\left.102^{\circ} 46^{\prime} 38^{\prime \prime} \mathrm{W}\right)$ in north-central Yoakum County, Texas. Since 1940 the area has been grazed by cattle during the summer, at a stocking rate of 19 ha per animal unit. The site had level topography, and soils were deep sands primarily of the Brownfield Series, a fine, mixed, thermic Arenic Aridic Paleustalfs (USDA 1964). Climate is warm, temperate, and semiarid (USDA 1964). Precipitation, like temperature, fluctuates widely with annual precipitation averaging $38 \mathrm{~cm}$, of which about $80 \%$ occurs from May to October. During this study precipitation $(28 \mathrm{~cm})$ exceeded the average for June through August by $55 \%$. 


\section{Mean daily temperatures were near normal.}

Sand shinnery oak, a deciduous $1-\mathrm{m}$ tall shrub, dominated the plant community on the site. Associated species included sand bluestem (Andropogon hallii Hack.), little bluestem [Schizachyrium scoparium (Michx.) Nash], sand dropseed [Sporobolus cryptandrus (Torr.) Gray], and threeawn (Aristida spp.). Common forbs were western ragweed (Ambrosia psilostachya DC.), Fendler euphorbia (Euphorbia fendleri T. \& G.), and threadleaf groundsel (Senecio riddellii T. \& G.). Sand sage (Artemisia filifolia Torr.), pricklypear (Opuntia spp.), and small soapweed (Yucca glauca Nutt.) also were present on the site.

\section{Field Study}

Ten esophageally fistulated wether goats ( 5 Angora and 5 Spanish) weighing an average of $31 \mathrm{~kg}$ were used to collect diet samples. The goats were maintained on alfalfa hay during the intervals between each (late June, mid-July, mid-August 1986) collection period. Following a 7-day adaptation period in the pasture, extrusa was collected for 30 min every morning at $0700 \mathrm{hr}$ for 5 consecutive days. Following collection, each extrusa sample was hand-mixed and frozen. Goats were released to resume grazing until $1900 \mathrm{hr}$, when they were penned in corrals, without feed, in preparation for the next morning collection and to avoid predation by coyotes. Water and trace mineral salt were provided ad libitum throughout the study.

Diet samples from each animal were pooled by period, divided into 2 subsamples, and freeze dried. One set of samples was ground to pass a $1-\mathrm{mm}$ screen in a Wiley mill, and aliquots were taken to determine dry matter (DM), organic matter (OM), crude protein (CP), neutral detergent fiber (NDF), acid detergent fiber (ADF), permanganate lignin (LIG), and in vitro organic matter digestibility (IVOMD). Dry matter was determined by oven-drying the samples at $105^{\circ} \mathrm{C}$ for $24 \mathrm{hr}$. Organic matter was determined by ashing DM samples at $550^{\circ} \mathrm{C}$ for $4 \mathrm{hr}$ (AOAC 1980). Nitrogen (N) was determined by a micro-Kjeldahl procedure and an automatic titrator, and $C P$ was calculated as $N \times 6.25$. Determinations of NDF and ADF were done according to the sequential fiber procedure (Van Soest and Robertson 1980). Lignin was extracted following Goering and Van Soest (1970). The IVOMD was determined by the two-stage procedure of Tilley and Terry (1963) with 3 tubes per extrusa sample. Ruminal inoculum for the in vitro procedure was obtained from a ruminally fistulated goat of each breed grazing the same pasture where diet samples were taken.

The second subsample was used to determine botanical composition of diets using the microscope point technique as outlined by Harker et al. (1964). Extrusa was systematically scanned at 10x magnification, and each of 100 points/sample was identified as shinnery oak, grass, forb, or others (primarily sand sage, pricklypear, and soapweed) as well as live or dead, and leaf, stem or flower-seed components.

Ten 30-kg wether goats (5 Angora and 5 Spanish) were fitted with fecal collection harnesses and bags (Pfister 1985) for estimation of nutrient intake. Fecal output was determined concomitantly with diet sampling, but animals were not penned at night. Total fecal output was collected every $12 \mathrm{hr}$ during the collection periods after a 7-day adaptation period to the pasture. A representative aliquot of each goat's daily sample was oven-dried at $65^{\circ} \mathrm{C}$, ground through a 1-mm screen, oven-dried at $105^{\circ} \mathrm{C}$ for $24 \mathrm{hr}$, and ashed at $550^{\circ} \mathrm{C}$ for $4 \mathrm{hr}$ to make dry matter and organic matter determinations, respectively (AOAC 1980).

Organic matter intake (OMI) was calculated using the fecal excretion: indigestibility ratio (Cordova et al. 1978). The in vitro digestibility estimate was the mean digestibility of extrusa from the 5 esophageally fistulated goats of each breed. Organic matter intake was calculated as a percent of body weight $(\% \mathrm{BW})$ as suggested by Van Soest (1982). Digestible energy intake was calcu- lated using the constant given by NRC (1981) of $4.62 \mathrm{Mcal} / \mathrm{kg}$ of digestible organic matter consumed.

At the end of each sampling period during July and August, samples of jugular blood were drawn from intact animals for blood urea nitrogen (BUN) determinations. Blood serum samples were put on ice until stored in an ultra freezer at $-40^{\circ} \mathrm{C}$. Blood serum was analyzed for urea nitrogen following the procedures of Fawcett and Scott (1960).

Available forage was determined monthly by clipping 30 randomly located $1.0-\mathrm{m}^{2}$ quadrats. Material was hand-separated into shinnery oak (current season's leaves and twigs), grasses, forbs, and other species (primarily sand sage, pricklypear, and soapweed). All material was air-dried and then oven dried at $65^{\circ} \mathrm{C}$ for 48 hours and dry weights recorded.

The ecologically important property of tannins has been suggested to be astringency, which influences palatability (McLeod 1974). Therefore, samples of current season leaves and twigs of shinnery oak were taken biweekly from 30 June to 13 September 1986 for tannin analysis. Samples were frozen and then freezedried. Condensed tannins were analyzed using an astringency (protein-complexing capacity) method (Horner et al. 1987). About $100 \mathrm{mg}$ of frozen leaf or stem tissue was ground using a mortar and pestle then extracted in $50 \%$ aqueous methanol in a tissue homogenizer. The methanol was removed by passing $\mathrm{N}_{2}$ over the supernatant while shaking in a $25-\mathrm{ml}$ Erlenmeyer flask submerged in a $55^{\circ} \mathrm{C}$ water bath. The sample was then filtered through a $0.45 \mu \mathrm{m}$ nylon membrane filter. Hemoglobin solution $[2.2 \mathrm{mg}$ of bovine hemoglobin substrate powder type Ii (Sigma Chemical Corporation) per $\mathrm{ml}$ of phosphate buffer, $\mathrm{pH}$ 6.5] was used as the reaction protein. The astringency of the plant tissue extract was expressed relative to that of spray-dried quebracho tannin (condensed tannin).

The experimental design used to test the hypotheses that diet composition, diet quality, forage intake, and blood urea- $\mathrm{N}$ were not influenced by breed of goat was completely random, using a repeated measures analysis of variance. Breed of goat was the main factor, and individual goats were nested within breed. Repeated measures were made each month on each individual animal. Data were analyzed using the Generalized Linear Model (GLM) of SAS (1985). No comparisons of oak tannin level or quality were possible since laboratory analyses were done on duplicate portions of single samples.

\section{Digestion Trial}

Current season's growth of sand shinnery oak (twigs and leaves) were hand-harvested from June to September of 1986. The harvested material was air-dried, combined and ground through a 5-mm screen, and mixed with ground alfalfa hay. Three experimental diets were prepared: (a) $95 \%$ alfalfa hay and $5 \%$ sugar cane molasses ( $0 \%$ oak); (b) $70 \%$ alfalfa hay, $5 \%$ molasses, and $25 \%$ shinnery oak ( $25 \%$ oak); and (c) $45 \%$ alfalfa hay, $5 \%$ molasses, and $50 \%$ shinnery oak ( $50 \%$ oak). Oak levels were chosen to correspond to dietary consumption by browsing goats (Villena 1987). The 5\% molasses was included as binding material to facilitate making pellets. Pellets were $2.5 \mathrm{~cm}$ long and $0.5 \mathrm{~cm}$ diameter, and compressed using minimum heat.

Six Angora wether goats ( $41 \pm 3 \mathrm{~kg}$ mean body weight) were fed the experimental diets between November of 1986 and January of 1987. The trials were conducted in metabolism cages located in a ventilated barn. Initially each diet was randomly assigned to 2 goats for 12 days. Thereafter, diets were assigned so that all 6 animals received each experimental diet for a 12-day period. A 7-day adaptation period was followed by a 5-day collection period, during which feces and urine were collected for laboratory analysis. Feed was offered once daily at $1300 \mathrm{hr}$. Amount offered was $10 \%$ to $20 \%$ greater than amount consumed the day before. Anim- 
als were provided fresh water and mineral salt ad libitum.

Feces and urine were collected once daily at $1400 \mathrm{hr}$. After weighing feces and determining urine volume of each animal, representative daily samples were taken. Fecal samples were stored in plastic whirl-pak bags and urine in plastic bottles. All samples were frozen at $-20^{\circ} \mathrm{C}$ for subsequent analysis. Feed samples were also taken for chemical analysis and IVOMD.

Fecal subsamples were freeze dried, and both feed and feces were ground to pass a $1-\mathrm{mm}$ screen in a Wiley mill. Dry matter and $O M$ of feed and feces were determined by oven-drying subsamples at $105^{\circ} \mathrm{C}$, and ashing for $4 \mathrm{hr}$ at $550^{\circ} \mathrm{C}$, respectively (AOAC 1980). For other chemical analyses, feces were pooled (by animal) over the 5-day collection period. Feed, feces, and urine were analyzed for $\mathrm{N}$ content by micro-Kjeldahl procedures (AOAC 1980). Feed and feces were also analyzed for NDF and ADF by the sequential fiber procedure (Van Soest and Robertson 1980) and LIG according to Goering and Van Soest (1970). Gross energy of feed and feces was determined by oxygen bomb calorimetry (Galyean 1984).

Apparent digestibility coefficients for $\mathrm{OM}, \mathrm{CP}$, cell contents (CC), NDF, ADF, and N were calculated. Digestibility coefficients for OM and CP of the pure oak ( $100 \%$ oak) were determined by extrapolating with linear regressions, using $O M$ and $C P$ digestion coefficients of shinnery oak for all levels of the experimental diets. The IVOMD of each diet was determined using the two-stage procedure of Tilley and Terry (1963). Ruminal inoculum was obtained from a ruminally fistulated Angora goat consuming the same experimental diets.

At the end of each sampling period, blood samples obtained by jugular venipuncture were collected for urea nitrogen (BUN) and tannic acid equivalent (TAE) determinations. Blood was collected in vacutainer tubes with no additives and then centrifuged to get serum. Blood serum was drawn off with plastic syringes and stored in sterile plastic tubes at $-40^{\circ} \mathrm{C}$. BUN was determined by a modified procedure of Fawcett and Scott (1960), and TAE by the procedure of Mosesson et al. (1947), as modified by Dollahite et al. (1962).

The experimental design was a replicated $3 \times 3$ Latin square design, and the data were evaluated statistically by analysis of variance procedures (SAS 1985). Orthogonal polynomials were used to test for linear and quadratic treatment effects (Steel and Torrie 1980).

\section{Results}

\section{Forage Availability}

Sand shinnery oak accounted for about $80 \%$ of the forage available on the site during the season (Table 1). Grasses contributed $18 \%$ of the season-long average, while available forbs comprised about $1 \%$. Other species contributed about $2 \%$ of the total available forage.

Although forbs were a minor component of the available forage ( 5 to $26 \mathrm{~kg} / \mathrm{ha}$ ), a large decline was noted from June to July (Table
Table 1. Standing crop ( $\mathrm{kg} / \mathrm{ha})$ of forage availability and diet composjtion ${ }^{1}(\%)$ of Angora and Spanish goats during 3 sampling periods.

\begin{tabular}{|c|c|c|c|c|c|c|}
\hline & \multicolumn{2}{|c|}{ June } & \multicolumn{2}{|c|}{ July } & \multicolumn{2}{|c|}{ August } \\
\hline & $\begin{array}{l}\text { Standing } \\
\text { crop }\end{array}$ & $\begin{array}{c}\% \\
\text { in diet }\end{array}$ & $\begin{array}{l}\text { Standing } \\
\text { crop }\end{array}$ & $\begin{array}{c}\% \\
\text { in diet }\end{array}$ & $\begin{array}{l}\text { Standing } \\
\text { crop }\end{array}$ & $\begin{array}{c}\% \\
\text { in diet }\end{array}$ \\
\hline Shinnery oak & $1323 \pm 384^{2}$ & $31.7 \mathrm{a}$ & $1078 \pm 454$ & $45.0 \mathrm{~b}$ & $1117 \pm 372$ & $55.1 \mathrm{c}$ \\
\hline Forbs $^{3}$ & $26 \pm 38$ & $22.8 \mathrm{a}$ & $5 \pm 12$ & $9.4 \mathrm{~b}$ & $9 \pm 40$ & $5.1 \mathrm{~b}$ \\
\hline Grass 4 & $244 \pm 273$ & 44.6 & $224 \pm 180$ & 44.8 & $340 \pm 274$ & 39.8 \\
\hline Other' & $53 \pm 119$ & 0.9 & $37 \pm 151$ & 0.8 & $4 \pm 10$ & 0 \\
\hline
\end{tabular}

'Main effect of breed (Angora vs Spanish) was not significantly different for any diet variable $(P>0.05)$.

2Standing crop means \pm 1 S.D. $(n=30)$.

${ }^{3}$ Main effect of months for diets was significant $(P<0.05)$ and diet means for months with different letters are significantly different $(P<0.05)$.

${ }^{4}$ Diet composition did not differ among months $(P>0.05)$.

1). Overall, total forage available declined from $1,646 \mathrm{~kg} / \mathrm{ha}$ in June to $1,344 \mathrm{~kg} / \mathrm{ha}$ in July, but did not decline thereafter.

\section{Dietary Botanical Composition}

Angora and Spanish goats had similar dietary composition throughout the summer (Table 1), as no differences were noted for any diet variable. Shinnery oak became an increasingly important diet constituent of both Spanish and Angora goats as the summer advanced (Table 1). In June, goats ate significantly less shinnery oak than in July and August. Grass remained constant in diets over time, averaging about $40 \%$ throughout the study. Selection of forbs declined significantly from June (22.9\%) to August (5.1\%). Interactions between breed and period were not found for any forage class.

Condensed tannin levels in shinnery oak ranged between 34 and $38 \mathrm{mg} / \mathrm{g}$ (dry weight) and did not change from June to September. Twigs contained slightly more tannin than did leaves (data not shown). Current season's growth of shinnery oak averaged $7.6 \%$ $\mathrm{CP}, 48.7 \%$ NDF, $15 \%$ lignin, and $35.7 \%$ IVOMD throughout the summer.

\section{Diet Quality and Intake}

Crude protein content of diets selected by Angora and Spanish goats was similar (Table 2). Dietary CP, across breeds, declined from June to July but increased during August. No breed $\times$ period interaction was found. Angora and Spanish goats selected diets similar in NDF and LIG content. Dietary fiber levels remained almost constant throughout the study periods (Table 2). The IVOMD of diets was similar for Angora and Spanish goats (Table 2). The IVOMD of diets decreased from June to July and August. There were period differences in IVOMD, but no breed $\times$ period interaction was found.

Spanish goats had higher mean OMI ( $1.4 \%$ of body weight) than did Angoras (1.2\%) (Table 3). Voluntary forage intake of goats increased as the summer progressed, and there was a breed $X$ period interaction. Both Angora and Spanish goats increased OMI

Table 2. Dietary chemical composition and in vitro digestlblity for Angora and Spanish goats graxing sand shinnery ouk ranges in Texas.

\begin{tabular}{|c|c|c|c|c|c|c|c|c|}
\hline \multirow{3}{*}{$\begin{array}{l}\text { Collection } \\
\text { period }\end{array}$} & \multicolumn{6}{|c|}{ Fiber components ${ }^{1}$} & \multirow{2}{*}{\multicolumn{2}{|c|}{ In vitro digestibility² }} \\
\hline & \multicolumn{2}{|c|}{ Crude protein ${ }^{1}$} & \multicolumn{2}{|c|}{ NDF } & \multicolumn{2}{|c|}{ LIG } & & \\
\hline & Angora & Spanish & Angora & Spanish & Angora & Spanish & Angora & Spanish \\
\hline $\begin{array}{l}\text { Jun } \\
\text { Jul } \\
\text { Aug } \\
\text { Means }\end{array}$ & \begin{tabular}{l|}
8.8 \\
8.3 \\
8.8 \\
$8.6 \mathrm{c}$
\end{tabular} & $\begin{array}{l}9.4 \\
8.1 \\
9.0 \\
8.8 c\end{array}$ & $\begin{array}{l}55.7 \\
56.9 \\
55.5 \\
56.0 \mathrm{c}\end{array}$ & $\begin{array}{l}52.1 \\
52.6 \\
52.7 \\
52.4 \mathrm{c}\end{array}$ & $\begin{array}{l}10.5 \\
11.7 \\
11.9 \\
11.4 \mathrm{c}\end{array}$ & $\begin{array}{l}11.0 \\
11.1 \\
11.9 \\
11.3 \mathrm{c}\end{array}$ & $\begin{array}{l}52.7 \\
45.0 \\
46.4 \\
47.7 \mathrm{c}\end{array}$ & $\begin{array}{l}47.0 \\
45.1 \\
43.7 \\
45.3 \mathrm{c}\end{array}$ \\
\hline
\end{tabular}

Percent of dry matter; NDF = neutral detergent fiber; LIG = lignin.

2Percent of organic matter.

${ }^{3}$ Means in same row and treatment comparison followed by the same letter do not differ $(P>0.05)$. 
Table 3. Daily forage and digestible energy intake, and blood urea nitrogen levels for Angora and Spaniah goats graxing oak ranges in Texas.

\begin{tabular}{|c|c|c|c|c|c|c|}
\hline \multirow{2}{*}{$\begin{array}{l}\text { Collection } \\
\text { period }\end{array}$} & \multicolumn{2}{|c|}{$\begin{array}{l}\text { Daily } \\
\text { Forage organic } \\
\text { matter intake }\end{array}$} & \multicolumn{2}{|c|}{$\begin{array}{c}\text { Daily digestible } \\
\text { energy intake }\end{array}$} & \multicolumn{2}{|c|}{$\begin{array}{c}\text { Blood urea } \\
\text { nitrogen }\end{array}$} \\
\hline & Angora & Spanish & Angora & Spanish & Angora & Spanish \\
\hline & \multicolumn{2}{|c|}{$-\%$ body weight -} & \multicolumn{2}{|c|}{-MCal-_ } & \multicolumn{2}{|c|}{$--\mathrm{mg} / 100 \mathrm{ml}-$} \\
\hline Jun & .9 & .9 & .9 & .7 & & \\
\hline Jul & 1.2 & 1.5 & .9 & $\ddot{1.1}$ & 10.6 & 11.1 \\
\hline Aug & 1.4 & 1.8 & 1.1 & 1.2 & 15.2 & 12.9 \\
\hline MeansI & $1.2 \mathrm{a}$ & $1.4 \mathrm{~b}$ & $.9 a$ & $.9 a$ & $12.8 \mathrm{a}$ & $11.9 a$ \\
\hline
\end{tabular}

Means in same row and treatment comparison followed by the same letter do not differ $(P>.05)$.

from June through August (Table 3). Although Angora and Spanish goats had similar OMI in June, Spanish goats had significantly higher intakes during July and August. No differences between breeds were noted for digestible energy intake (DEI) (Table 3). Angora goats had similar DEI during June and July, but increased DEI during August. Spanish goats also increased DEI from June to August.

Blood urea $N$ concentrations were not different between Angora and Spanish goats (Table 3). BUN concentration increased from July to August. Although BUN increased in both goat breeds as the season progressed, such increments were higher for Angora than for Spanish goats.

\section{Digestion Trial}

Oak-containing diets (Table 4) were lower in crude protein (CP), cell contents (CC), and in vitro organic matter digestibility (IVOMD), but higher in neut ral detergent fiber (NDF), acid detergent fiber (ADF), and lignin (LIG) than the control diet ( $0 \%$ oak).

Table 4. Chemical composition and in vitro organic matter digestibility (IVOMD) of experimental diets (dry basis) consumed by goats.

\begin{tabular}{lccc}
\hline \hline & \multicolumn{3}{c}{ Levels of shinnery oak (\%) } \\
\cline { 2 - 4 } Fractions & 0 & 25 & 50 \\
\hline Crude protein, \% & 19.8 & 18.0 & 13.9 \\
Digestible protein ${ }^{1}, \mathrm{~g} / 100 \mathrm{~g}$ & 14.9 & 11.9 & 6.3 \\
Cell contents, \% & 65.3 & 64.1 & 59.0 \\
Neutral detergent fiber, \% & 34.8 & 35.9 & 41.0 \\
Acid detergent fiber, \% & 28.3 & 28.0 & 33.5 \\
Lignin, \% & 8.8 & 11.4 & 13.0 \\
IVOMD, \% & 80.6 & 69.2 & 60.9 \\
\hline
\end{tabular}

'Calculated from crude protein content of feed and apparent protein digestibility. Digestible protein $(Y)$ and crude protein $(X)$ were related by the equation $(Y=-13.81+$ $1.44(\mathrm{X}), \mathrm{r}^{2}=.99, \mathrm{n}=3$.

The oak used to formulate the diets contained $37 \mathrm{mg}$ of condensed tannin/g of dry matter (Villena 1987).

Digestibility of $\mathrm{OM}, \mathrm{CP}, \mathrm{CC}$, and NDF, but not ADF, decreased linearly with increased shinnery oak levels in the diets (Table 5). The regression equation for $\mathrm{OM}$ digestibility was $\mathrm{Y}=$ $67.317-.294 \mathrm{X}\left(r^{2}=.98 ; \mathrm{S}_{\mathrm{y.x}}=.57 ; \mathrm{n}=18\right)$, and for CP digestibility, the equation was $Y=77.117-.598 X\left(r^{2}=.90 ; S_{y . x}=4.20 ; n=18\right)$, where $Y$ is $O M$ or CP digestibility and $X$ is the 3 levels of oak in the diets. From these regression equations, $\mathrm{OM}$ and $\mathrm{CP}$ digestibility of the pure oak (100\%) was extrapolated to be $37.9 \%$ and $17.3 \%$, respectively.

Voluntary intake of organic matter, expressed as percentage of body weight (\%BW), was not affected by the levels of oak in the diets (Table 6). However, CP and energy intake decreased linearly when the level of oak reached $50 \%$ of the experimental diet.

Fecal $\mathrm{N}$ increased and urinary $\mathrm{N}$ decreased linearly with increasing levels of dietary oak (Table 7). The amount and the proportion
Table 5. Apparent digestibility coefficients of the chemical constituents in the experimental diets consumed by goats.

\begin{tabular}{lccc}
\hline \hline & \multicolumn{3}{c}{ Levels of shinnery oak (\%) } \\
\cline { 2 - 4 } Items, \% & 0 & 25 & 50 \\
\hline Organic matter $^{1}$ & 67.1 & 60.4 & 52.4 \\
Crude protein $^{1,2}$ & 75.2 & 66.0 & 45.3 \\
Cell contents $^{1}$ & 77.6 & 71.9 & 62.8 \\
Neutral detergent fiber $^{1}$ & 46.8 & 38.3 & 35.0 \\
Acid detergent fiber $^{3}$ & 40.6 & 29.7 & 32.8 \\
\hline
\end{tabular}

'Linear treatment effect $(P<0.05)$

2Quadratic treatment effect $(P<0.05)$

No treatment effect $(P>0.05)$

of $\mathrm{N}$ apparently digested decreased with increasing levels of oak (Table 7). The amount and the proportion of $\mathrm{N}$ retained showed a positive quadratic response to the low oak level, and then declined at the $50 \%$ oak level. The percentage of absorbed $\mathrm{N}$ that was retained showed a linear increase as oak level increased. There was no relationship between $N$ intake $(g)$ and fecal $N$ levels $\left(r^{2}=0.02, n\right.$ $=18$ ).

Table 6. Voluntary intake of organic matter, crude protein and digestible energy of experimental diets consumed by goats.

\begin{tabular}{lrrr}
\hline \hline & \multicolumn{3}{c}{ Levels of shinnery oak (\%) } \\
\cline { 2 - 4 } Intake & \multicolumn{1}{c}{0} & \multicolumn{1}{c}{25} & \multicolumn{1}{c}{50} \\
\hline Organic matter, \% BW & 2.2 & 2.9 & 2.9 \\
Crude protein, g/day $^{3}$ & 2.6 & 245.9 & 182.5 \\
Digestible energy, Mcal/day $^{3}$ & 245.5 & 3.5 & 2.9 \\
\hline
\end{tabular}

'Body weight

2No treatment effect $(P>0.05)$

${ }^{3}$ Linear treatment effect $(P<0.05)$

The level of BUN decreased 15-20\% with increased levels of oak in the diets, but BUN levels for all diets were within normal ranges $(13-20 \mathrm{mg} / 100 \mathrm{ml})$. Tannic acid equivalent was not detected in sera of the experimental animals.

\section{Discussion}

Spanish and Angora goats consumed diets similar in botanical composition throughout the study period. Taylor (1975) and Merrill and Taylor (1976) suggested that Spanish goats will more extensively utilize browse than will Angora goats. Warren et al. (1984) reported that Spanish goats consumed more browse than did Angora goats, and indicated that diet selection by Angoras more closely resembled Barbado sheep than Spanish goats. In this study, Spanish goats did not appear to be better adapted than Angora goats for browsing sand shinnery oak ranges.

Availability of forbs may have influenced consumption of oak by goats. Huston et al. (1981) have classified forbs as quality components of available forage in Texas. Although forbs were only $1 \%$ of the total forage available (Table 1), they were an important constituent of the goat's diets. As forb availability decreased, goats may have shifted diets to select more oak instead of grass.

Several studies have reported that goats are best classified as browsers (McMahan 1964, Sidahmed et al. 1981, Warren et al. 1984) since their diets often contain $50 \%$ or more browse. However, others have suggested that goats are best categorized as intermediate feeders (Pfister and Malechek 1986, Migongo-Bake and Hansen 1987), or opportunistic generalists (Coblentz 1977). This study supports the latter view, since goats consumed diets nearly equivalent in grass and browse percentages, even though $80 \%$ of available forage was shinnery oak. 
Table 7. Daily nitrogen balance of goats consuming the experimental oak diets.

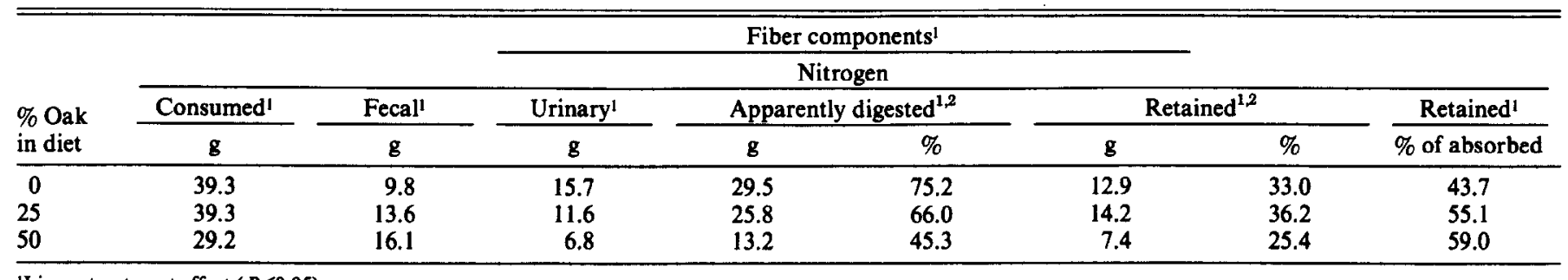

'Linear treatment effect $(P<0.05)$

${ }^{2} Q u a d r a t i c$ treatment effect $(P<0.05)$

Oak tannin levels in this study were much lower than reported by Pidgeon et al. (1962). The methods used by Pidgeon et al. (1962) to extract and quantify hydrolyzable shinnery oak tannins are not comparable to the method used to determine condensed tannins in this study. Hydrolyzable tannins may be toxic agents (Pidgeon et al. 1962), but condensed tannins likely have a greater influence on palatability and consumption of browse (Cooper and Owen-Smith 1985).

The relationship between tannin levels in oakbrush and palatability was not clear. Although tannin levels remained constant, goats consumed more oak as the summer progressed. Even though adaptation periods were used before each sampling period, goats may have gained browsing experience over the course of the summer (Hodgson 1982). Further, animals' adaptation to dietary tannins through increased salivary secretion of proline (Mehansho et al. 1983) may have occurred as the season progressed (Robbins et al. 1987a). Salivary proline has a high affinity for tannins (Mehansho et al. 1983), and may reduce the level of tannins available for interference with digestion (Cooper and Owen-Smith 1985, Asquith and Butler 1986, Mehansho et al. 1987).

Both Angora and Spanish goats grazing this vegetation community selected diets with similar levels of nutrients. Dietary $C P$ levels were slightly lower than those reported by Bryant et al. (1980) for the same breeds grazing range of excellent condition in the Edwards Plateau, and values are close to the average reported by Lopes and Stuth (1984) for goats grazing Texas Savannah during summer. The percentage of $\mathrm{CP}$ in the diets would satisfy goats'maintenance requirements (NRC 1981, Devendra and Burns 1983) when grazing shinnery oak rangeland during the summer. However, based on the level of dietary CP and intake, the amount of daily CP consumed would not be enough for maintenance plus medium activity of goats under range situations, particularly during early summer when intakes were low.

Dietary IVOMD declined from June to July and August, even though dietary cell wall components did not change significantly. One factor that may have contributed to decreased digestibility was increased consumption of oak (Table 2), a species of low digestibility. High lignin content of oak was probably a major factor in the low in vitro digestibility values (Van Soest 1982). Lopes and Stuth (1984) and Pfister and Malechek (1986b) also found that IVOMD of goats' diets declined with increasing amounts of dietary browse.

Little research has been done to determine intake of goats under free grazing conditions. Pfister and Malechek (1986b) found that goats grazing deciduous shrub-woodland in northeastern Brazil had an organic matter intake of $2.1 \%$ of BW. McCammonFeldman (1980) reported an intake of $2.3 \%$ of BW for Nicaraguan goats. The results of the present study are lower than noted in those studies, but environmental conditions were also very different. Voluntary intake increased over the summer, as did DEI. Digestible energy intake was lower than that recommended by NRC (1981) for maintenance and medium activity of a goat of $30 \mathrm{~kg}$ body weight under range conditions ( $2.38 \mathrm{Mcal} /$ day). Pfister and
Malechek (1986b) reported DEI for Brazilian goats of $1.3 \mathrm{Mcal} /$ day. Higher DEI (3.4 to $5.6 \mathrm{Mcal} /$ day) than found in this study were reported by Griego (1977) for goats grazing the Tunisian Pre-Sahara range. Increases in OMI and DEI occurred despite the reduction in dietary IVOMD as the summer progressed. This may have been due to animals' adapting to dietary tannins through salivary binding (Mehansho et al. 1983), or may have reflected increased adaptation of goats for this type of shrub rangeland, or both. Goats may also have increased intakes through compensatory increases in gut fill. Increases in gut fill with forage maturation have been documented in cattle (McCollum and Galyean 1985), and for deer on browse diets (Baker and Hobbs 1987).

\section{Digestion Trial}

The nutritional quality of the experimental diets decreased as the proportion of shinnery oak increased, due to the lower nutritional quality of shinnery oak compared to alfalfa. As a result, digestibility of all constituents except ADF was significantly reduced by increasing the level of shinnery oak in the diets. Nastis and Malechek (1981) also found similar trends when oak was added to a basal diet.

Reductions in cell wall digestibility due to tannins in forage have been reported by Barry and Manley (1984) for sheep. Digestion of cell wall fiber (NDF) was only marginally related to lignin content of the diets $\left(r^{2}=.44, n=18\right)$, indicating that factors other than lignin were also depressing cell wall digestion. Such factors may be digestion inhibitors such as tannins, or antiquality factors, such as silica or cutin (Van Soest 1982). Robbins et al. (1987b) found no influence of tannins on cell wall digestion in deer on high-tannin diets, while Nastis and Malecheck (1981) reported reductions in cell wall digestion from mature but not young oak browse. We found a significant reduction in digestion of cell solubles. Robbins et al. (1987b) also noted large reductions in digestion of cell contents in deer eating browse. There was no apparent relationship between digestion of cell contents and amount of cell contents $\left(r^{2}=\right.$ $.16, \mathrm{n}=18$ ) in the experimental diets.

The low CP digestibility for shinnery oak found in this study (17.3\%) was either a result of tannins acting to reduce digestion (McLeod 1974), or was due to the nondigestible, fiber-bound protein in oak browse. Robbins et al. (1987a) found that leaf tannins from deciduous shrubs reduced protein digestibility in deer. However, Robbins et al. (1987a) also noted that protein digestibility was reduced in grasses with no tannins due to increases in fiber-bound protein.

There was an increase in fecal $\mathrm{N}$ and decrease in urinary $\mathrm{N}$ with higher levels of dietary shinnery oak. The amount of $\mathbf{N}$ absorbed from the small intestine was reduced at the highest oak level. Elevated levels of fecal $\mathrm{N}$ and reduced absorption may be due to tannin-protein complexes resistant to digestion, or to undegradable fiber-bound proteins in oak.

Voluntary intake was not influenced by increased levels of shinnery oak in the diets, contrary to finding of Nastis and Malechek (1981). Nastis and Malechek (1981) indicated that declining 
digestibility with the incorporation of oak into a basal diet produced a significant reduction in intake. In this study, however, OM digestibility declined but $O M$ intake was similar between treatments. We speculate that the use of molasses as a binder in the pellets may have improved intakes. Further, pelleting may have influenced retention times in the rumen. Also, shrubs have been reported to have thin cell walls, which facilitates rapid digestion of cell solubles and greater intake (Holechek 1983, Holechek and Vavra 1983). Another factor that may have helped maintain voluntary intake as the level of dietary shinnery oak increased is an increase in gut capacity. Cattle can increase gut capacity when forage quality decreases (McCollum and Galyean 1985). Baker and Hobbs (1987) found that mule deer increased intake on diets high in browse by increasing gut fill rather than passage rate.

Goats showed no evidence of intoxication when consuming shinnery oak in pen-fed or under free-grazing conditions. The lack of toxicity is substantiated by the normal levels of BUN. We conclude the shinnery oak can contribute substantially to the nutrition of goats foraging on these rangelands. The long-term impact of goat browsing on this vegetation type may provide some shifts towards more grasses, and eventually enhance cattle grazing on these ranges.

\section{Literature Cited}

Allison, C.D. 1985. Factors affecting forage intake by range ruminants: A review. J. Range Manage. 38:305.

AOAC. 1980. Official methods of analysis (13th Ed.). Association of Official Analytical Chemists, Washington, D.C.

Asquith, T.N., and L.F. Butler. 1986. Interactions of condensed tannins with selected proteins. Phytochem. 25:1591.

Baker, D.L., and N.T. Hobbs. 1987. Strategies of digestion: digestive efficiency and retention time of forage diets in montane ungulates. Can. J. Zool. 65:1978.

Barry, T.N., and T.R. Manley. 1984. The role of condensed tannins in the nutritional value of Lotus pendunculatus for sheep: Quantitative digestion of carbohydrates and proteins. Brit. J. Nutr. 51:493.

Bryant, F.C., M.M. Kothmann, and L.B. Merrill. 1980. Nutritive content of sheep, goat and white-tailed deer diets on excellent condition rangeland in Texas. J. Range Manage. 33:410.

Coblentz, B.E. 1977. Some range relationships of feral goats on Santa Catalina Island, California. J. Range Manage. 30:415.

Cooper, S.M., and N. Owen-Smith. 1985. Condensed tannins deter feeding by browsing ruminants in South African savanna. Oecologia 67:142.

Cordova, F.J., J.D. Wallace, and R.D. Pieper. 1978. Forage intake by grazing livestock: A review. J. Range Manage. 31:430.

Devendra, C., and M. Burns. 1983. Goat production in the tropics. Commonwealth Agricultural Bureaux, London.

Dollahite, J.W., R.F. Pigeon, and B.J. Camp. 1962. The toxicity of gallic acid, pyrogallol, tannic acid and Quercus havardii in the rabbit. Amer. J. Vet. Res. 23:1264.

Fawcett, J.K., and J.E. Scott. 1960. A rapid and precise method for the determination of urea. J. Clin. Path. 13:156.

Galyean, M. 1984. Techniques and procedures in animal nutrition research. New Mexico State Univ., Dep. Anim.and Range Sci., Las Cruces.

Goering, H.K., and P.J. Van Soest. 1970. Forage fiber Analyses. Agr. Handb. No. 379. ARS, USDA, Washington, D.C.

Griego, R.C. 1977. Forage selection and nutrition of sheep and goats grazing in the Tunisian Pre-Sahara. M.S. Thesis. Utah State Univ., Logan.

Harker, K.W., D.T. Torrell, and G.M. Van Dyne. 1964. Botanical examination of forage from esophageal fistulas in cattle. J. Anim. Sci. 23:465.

Hodgson, J. 1982. Influence of sward characteristics in diet selection and herbage intake by grazing animal. pp 153-166. In. J.B. Hacker (Ed.). Nutritional limits to animal production from pastures. CSIRO, Queensland, Australia.

Holechek, J.L. 1983. Comparative nutritional value of grasses, forbs and shrubs for range ruminants: A review: Agr. Exp. Sta. New Mexico State Univ., Las Cruces.

Holechek, J.L., and M. Vavra. 1983. Drought effects on diet and weight gains of yearling heifers in northeastern Oregon. J. Range Manage. 36:227.
Horner, J., R.G. Cages, and J. Gosz. 1987. Tannin, nitrogen, and cell wall composition of green vs. senescent Douglas-fir foliage: Within and between-stand differences in stands of unequal density. Oecologia 72:515.

Huston, J.E. 1978. Forage utilization and nutrient requirements of the goat. J. Dairy Sci. 61:988.

Huston, J.E., B.S. Rector, L.B. Merrill, and B.S. Ingdall. 1981. Nutritive value of range plants in the Edward Plateau region of Texas. Tex. Agr. Exp. Sta. Bull. 1357

Lopes, E.A., and J.W. Stuth. 1984. Dietary selection and nutrition of Spanish goats as influenced by brush management. J. Range Manage. 37:554.

Malechek, J.C., and F.D. Provenza. 1983. Feeding behavior and nutrition of goats on rangelands. World Anim. Rev. 47:38.

McCammon-Feldman, B. 1980. A critical analysis of tropical savanna forage consumption and utilization by goats. Ph.D. Diss., Univ. of Illinois, Urbana.

McCollum, F.T., and M.L. Galyean. 1985. Cattle grazing blue grama rangeland II. Seasonal forage intake and digesta kinetics. J. Range Manage. 38:543

McLeod, M.N. 1974. Plant tannins-their role in forage quality. Nutr. Abst. Rev. 44:804

McMahan, C.A. 1964. Comparative food habits of deer and three classes of livestock. J. Wildl. Manage. 28:798.

Mehansho, H., L.F. Butler, and D.M. Carlson. 1987. Dietary tannins and salivary proline-rich proteins: Interactions, induction, and defense mechanisms. Annul. Rev. Nutr. 7:423.

Mehansho, H., A. Hagerman, S. Clements, L. Butler, J. Rogler, and D.M. Carlson. 1983. Modulation of proline-rich protein biosynthesis in rat parotid glands by sorghums with high tannin levels. Proc. Nat. Acad. Sci. USA 80:3948.

Merrill, L.B., and C.A. Taylor. 1976. The role of goats in biological control of brush. Beef Sci. Handb. 12:372.

Migongo-Bake, W., and R.M. Hansen. 1987. Seasonal diets of camels, cattle, sheep, and goats in a common range in eastern Africa. J. Range Manage. 40:76.

Mosesson, E., B. Norberg, H. Rosenqvist, and F. Wahlgren. 1947. On the toxic effect of tannic acid with reference to the treatment of burns. Acta Physiol. Scand. 14:144.

Nastis, A.S., and J.C. Malechek. 1981. Digestion and utilization of nutrients in oak browse by goats. J. Anim. Sci. 53:283.

NRC. 1981. Nutrient requirements of goats: Angora, dairy, and meat goats in temperate and tropical countries No. 15. Nat. Acad. Sci., Nat. Res. Counc. Washington, D.C.

Pfister, J.A. 1985. An effective fecal harness for free grazing goats. J. Range Manage. 38:184.

Pfister, J.A., and J.C. Malechek. 1986a. Dietary selection by goats and sheep in a deciduous woodland of northeastern Brazil. J. Range Manage. 39:24.

Prister, J.A., and J.C. Malechek. 1986b. The voluntary intake and nutrition of goats and sheep in the semi-arid tropics of northeastern Brazil. J. Anim. Sci. 63:1078.

Pidgeon, R.F., B.J. Camp, and J.W. Dollahite. 1962. Oral toxicity and polyhydroxyphenol moiety of tannin isolated from Quercus havardii (shin oak). Amer. J. Vet. Res. 23:1268.

Provenza, F.D., and J.C. Malechek. 1984. Diet selection by domestic goats in relation to blackbrush twig chemistry. J. Appl. Ecol. 21:831.

Robbins, C.T., T.A. Hanley, A.E. Hagerman, O. Hjeljord, D.L. Baker, C.C. Schwartz, and W.W. Mautz. 1987a. Role of tannins in defending plants against ruminants: reduction in protein availability. Ecology 68:98.

Robbins, C.T., S. Mole, A.E. Hagerman, and T.A. Hanley. 1987b. Role of tannins in defending plants against ruminants: reduction in dry matter digestion? Ecology 68:1606.

SAS Users Guide: Statistics. 1985. SAS Inst., Inc., Cary, NC.

Sears, W.E., C.M. Britton, D.B. Wester, and R.D. Pettit. 1986. Herbicide conversion of a sand shinnery oak (Quercus havardii) community: effects on nitrogen. J. Range Manage. 39:403.

Sidahmed, A.E., J.G. Morris, and S.R. Radosevich. 1981. Summer diet of Spanish goats grazing chaparral. J. Range Manage. 34:33.

Steel, R.D.G., and J.H. Torrie. 1980. Principles and Practices of Statistics (2nd Ed.) McGraw-Hill Book Co., New York.

Taylor, G. 1975. Spanish versus Angora goats in controlling browse. The Ranch Magazine.

Tilley,J.M.A., and R.A. Terry. 1963. A two-stage technique for the in vitro digestion of forage crops. J. Brit. Grassl. Soc. 18:104. 
USDA. 1964. Soil survey of Yoakum county, Tex. Agr. Exp. Sta. Ser. 1960. No. 15.

Van Soest, P.J. 1982. Nutritional ecology of the ruminant. O \& B Books, Corvallis, Ore.

Van Soest, P.J., and J.B. Robertson. 1980. Systems of analysis for evaluating fibrous feeds. pp. 49-60. In: W.J. Pigden, C.C. Balch, and M. Graham (Ed.). Standardization of analytical methodology for feeds: Proc. Workshop, Ottawa, Canada, 12-14 March 1979. IDRC-1343, Ottawa.
Villem, F. 1987. Nutrition of goats grazing sand shinnery oak (Quercus havardii) ranges in West Texas. M.S. Thesis. Texas Tech Univ., Lubbock.

Warren, L.E., D.N. Ueckert, M. Shelton, and A.D. Chamrad. 1984. Spanish goat diets on a mixed-brush rangeland in the south Texas plains. J. Range Manage. 37:340. 